\title{
A Reconciled Maid: A Lover's Complaint and Confessional Practices in Early Modern England
}

\author{
Paul Stegner
}

In A Lover's Complaint, Shakespeare registers concerns about a penitent's inability to overcome the effects of sin and emphasizes the importance of private or auricular confession. By representing what amounts to be the confession of a 'fickle maid' (5) to a 'reverend man' (57), Shakespeare underscores the paradox of the Protestant confessional model: if a penitent can be forgiven of sins without priestly intervention, what happens when he or she does not experience consolation?' By modeling the poem on the conventional rite of penance, Shakespeare creates a poetic space in which to explore the intense effects of seduction and desire (as James Schiffer, Stephen Whitworth, and Jon Harned indicate in their respective essays in this volume), but also to demonstrate the limitations of individual subjectivity in overcoming the Christian economy of shame and guilt.

Critics have long recognized that the poem resembles a 'would-be confession' but often diminish the significance of this representation by arguing that the fickle maid overreacts to her situation, or that she comes to terms with the young man's sexual betrayal (Rollins 595). ${ }^{2}$ Even John Kerrigan, who provides an exceptional study of the poem's religious and confessional context, minimizes its theological dimension: 'As the title insists A Louer's Complaint is amorous. Whatever the importance of "confessioun" and repentance elsewhere, this poem is about love' (Kerrigan, Motives of Woe 41). Nevertheless, by using charged theological language throughout the poem, Shakespeare makes no distinction between sexual or romantic desire and the religious context in which the fickle maid operates. On the contrary, he connects desire to ritual to emphasize their intertwined and problematic relationship.

From the numerous 'maimed rites' in Hamlet (5.2.219) to the anxiety over 'the priest in surplice white' completing the requiem in 'The Phoenix and Turtle' (13), Shakespeare grounds the assurance of consolation in the fulfillment of ecclesiastical rituals. Shakespeare's engagement with what David Cressy describes as the 'profoundly traumatic' repercussions stemming from the Church of England's disruption of various ritual practices has become the subject of much attention (477). Most notably, critics such as Robert Watson, Michael Neill, Stephen Greenblatt, and John Klause have examined the fallout from the English Church's rejection of the prayers for the dead and the doctrine of Purgatory. Nevertheless, the connection between Shakespeare's representations of private confession and the Established Church's attack on sacramental penance and its reorientation of 
confessional practices remains largely overlooked. This critical neglect is notable given Shakespeare's repeated depictions of the rite, such as Claudius' failed confession in Hamlet and Duke Vicentio's problematic role as a confessor in Measure for Measure. In many ways, this oversight results from the assumption that the issue of confession was easily resolved and remained unchanged after Elizabeth's accession. Instead of passing away quietly or being consolidated, though, auricular penance remained a contentious issue in the Church of England throughout the early modern period. Moreover, the changes to confessional practices, especially auricular confession, radically altered an individual's relationship to God and to self.

A Lover's Complaint is indeed Shakespeare's most sustained treatment of the trauma caused by the transformation of penance in Tudor England. As part of the Reformation, the Church of England rejected the sacramental quality and necessity of confession and decentered its place in the lives of the faithful. No longer required to confess sins to a priest annually, individuals were expected to seek forgiveness directly from God. Penitents could not rely upon a priest's absolution to effect grace, the conventional Catholic teaching on private confession, but had to depend on their individual subjectivity and self-knowledge. A minister's 'private absolution', as Richard Hooker explains, 'can be noe more then a declaration of what God hath done' (3: 82). The elevation of interior subjectivity in the Established Church provided those with an assurance of faith the ability to confess to God without ecclesiastical mediation, but it offered only nominal assistance to those incapable of negotiating sin and overcoming self-doubts. As a result, the Church of England's effective abandonment of auricular confession disrupted the established ritual practices of many of the faithful.

By offering a concentrated representation of confession in A Lover's Complaint, Shakespeare foregrounds the estrangement resulting from this reconfigured model of auricular penance. His depiction of a 'fickle maid' who cannot experience consolation even though she is 'reconciled' reflects the renewed discourses on confession at the beginning of the seventeenth century (329). Shakespeare's advancement of the need for ritualized confession to achieve consolation corresponds to the position of Lancelot Andrewes, whose 1600 sermon entitled $O f$ the Power of Absolution intimates the necessity of priestly absolution. Indeed, in $A$ Lover's Complaint, without the fulfillment of the rite of penance, namely, the reverend man's absolution, the fickle maid remains infected by the seductive rhetoric of the young man regardless of her spiritual reconciliation. Shakespeare depicts an interrupted confessional rite to illustrate not only the necessary intersection between ritual and self, but also the limitations of individual subjectivity separated from ritual practices. To explore in more detail Shakespeare's representation of auricular confession in the poem, I first outline the development of confessional practices during the English Reformation. I then examine how the penitential form of A Lover's Complaint underscores what Thomas Tentler has identified as the central question of confession: ' $[\mathrm{H}]$ ow does the sinner know that he is forgiven?' (14). Finally, I demonstrate the significance of the poem's confessional structure in relation to Shakespeare's construction of interior subjectivity in Shakespeares Sonnets, the 1609 quarto that prints A Lover's Complaint as a complementary female complaint to Shakespeare's sonnet sequence. ${ }^{4}$ 
I.

The Reformation attack on sacramental confession rested on two primary, often interlinked, objections: (1) reformers like Calvin and Zwingli rejected the sacramental status of confession outright because they denied it had been explicitly instituted by Christ; and (2) reformers like Luther critiqued auricular confession because of the close association of mandatory confession with ecclesiastical authority embodied in the 'power of the keys' which Christ imparts to St. Peter: 'And I will give unto thee the keyes of the kingdome of heaven: and whatsoever thou shalt bind on earth shall be bound in heaven: and whatsoever thou shalt loose on earth, shall be loosed in heaven' (Matt. 16:19, Geneva Bible). The medieval church traditionally used the keys to justify papal and clerical authority and jurisdiction. This connection between confession and ecclesiastical authority led Luther, who had found scriptural authorization for confession in James 5:16, 'confitemini ergo alterutrum vestra' [confess your sins to one another], to attempt to reform the practice. By critiquing the Church's abuse of sacerdotal authority over auricular confession, then, sixteenth-century reformers intended, on a general level, to rectify the perceived failings of the medieval church and, on a particular level, to obviate the penitential practices instituted by the Fourth Lateran Council in 1215 .

Before the council, Christians confessed their sins irregularly if at all, but, as a result of the Omnia utriusque sexus, the twenty-first canon of the council, all Christians who had reached the age of reason-between fourteen and seventeen years old-were required to confess their sins to a priest at least once a year. These reforms dramatically transformed the penitential landscape of Latin Christianity. Since, as Ronald Rittgers observes, 'confession and communion went together in the minds of both Church officials and the laity,' the power vested in a confessor was considerable because he possessed authority over not only a Christian's outward relationship with the church, but also his or her inward, spiritual relationship with Christ (26). In the person of the confessor, the faithful literally experienced the clergy's fulfillment of Christ's words to St. Peter to bind and loose sins.

While the reformers certainly had no intention of returning to the pre-Lateran state of Christian penance and discipline, their solutions for the fate of confession varied widely. For reformers who wanted to maintain sacramental confession, the answer was to reform the institution. Emphasizing the consolatory power of confession, Luther, for instance, praised the benefits of confession: 'I will allow no man to take private confession away from me, and I would not give it up for all the treasures of the world, since I know what comfort and strength it has given me' (51: 98). Despite Luther's praises, he attacked the corruption of the rite of penance under the medieval clergy: 'Thus the most salutary sacrament of penance has become nothing but sheer tyranny ... a disease and a means to increase sins' (qtd. in Ozment 50). Luther's condemnation of sacerdotal abuses thus outweighed his commendation of penitential acts, and ultimately his reorientation of private confession radically altered its place in Christian life. Reformers like Calvin who completely abolished sacramental confession and who shifted their emphasis to the general confession in religious services nevertheless continued to practice a form of private confession. For those reformers who retained some form of private confession, it became secondary to public confession in a religious setting and reserved as an exceptional 
means for comforting the faithful. Calvin's comment that it should be used for those 'so agonized and afflicted by a sense of [their] sins that [they] cannot obtain relief without the aid of others' reflects the relegation of auricular confession to such extraordinary circumstances $(1: 544)$.

Along with the reformers' transformation of the medieval church's practice of auricular confession, they denied the sacerdotal authority over the power of the keys. Luther asserted the power of the keys had been granted to all Christians; as such, forgiveness could be accomplished by 'a brother or a neighbor ... in the house or the fields,' but, more preferably, by a penitent's faith in God's mercy (qtd. in Kerrigan, Motives of Woe 40). In contrast with the medieval church's emphasis on the priest's power to absolve sins, Luther stressed that the authority to remit sins belonged only to God. Luther summarizes this view in the Babylonian Captivity of the Church (1520): 'Once faith is possessed, contrition and consolation will come as the inevitable and spontaneous consequence' (qtd. in Tentler 369). Likewise, Calvin, declaring that sacerdotal jurisdiction over confession was one of the many "frivolous absurdities' of Roman Catholicism, explained: '[W]e are to deposit our infirmities in the breasts of each other, with the view of receiving mutual counsel, sympathy, and comfort' (1: 539). Instead of relying upon a ghostly confessor to remit sins, Luther and Calvin concentrated on the penitent's faith in God's forgiveness.

Drawing upon earlier moderate reformers' models of private confession, the Church of England retained a reformed model of auricular confession that emphasized an individual's direct confession to God. William Tyndale's comments in The Exposition of the Fyrste Epistle of Seynt Jhon (1531) illustrate the position of many of the early English reformers toward a reformed model of auricular confession: 'If we confess our sins, not in the priest's ear (though that tradition, restored to the right use, were not damnable), but in our hearts to God, with true repentance and fast belief; then is he faithful to forgive and to purge us, because of his merciful truth and promise' (qtd. in T.T. Parker 110). Furthermore, with the publication of The Order of Communion (1548), the Established Church affirmed that auricular confession was no longer necessary for the faithful and thereby allied itself with the Calvinist understanding of penance. Yet, unlike Calvin's and Luther's abolishment of sacerdotal control of auricular confession, the Church of England maintained the medieval church's restriction of its administration to the clergy. In The Order of Communion the jurisdiction of priests is clearly outlined: 'And if there be any of you whose conscience is troubled and grieved in any thing, lacking comfort or counsel, let him come to me, or to some other discreet and learned Priest taught in the law of God, and confess and open his sin and grief secretly' (Ketley 61-62). ${ }^{6}$ Taking the media via, the Church of England stressed the importance of an individual conscience in confession, but preserved the ecclesiastical authority of the clergy.

In the Elizabethan Church, auricular confession became an exceptional means under sacerdotal authority for reconciling and comforting those faithful who could not achieve a quiet conscience on their own. The Book of Common Prayer (1559) instructs the priest, if he perceives an individual who 'cannot quiet his own conscience, but requireth further comfort of counsel,' to declare: '[T]hen let him come to me, or some other discrete and learned minister of God's Word, and open his grief, that he may receive such ghostly counsel, advice, and comfort, as his 
conscience may be relieved' (Booty 257). After the institution of the 1559 Prayer Book, the doctrinal issues surrounding confession and absolution remained dormant and private confession all but disappeared in the religious life of the Established Church. In practice, those who privately confessed were generally limited, as Kenneth Parker notes, to 'a self-selected clientele: the godly' (70). The neglect of private confession resulted in part from the church's doctrinal leanings toward Calvinism. Private confession thus existed as an extraordinary means to console scrupulous penitents by leading them to recognize that they have received divine absolution.

At the end of the sixteenth century, however, the issue of auricular confession reemerged at Cambridge. At the center of this controversy was John Overall, Regius Professor of Divinity, who faced criticism in 1600 over his teaching on auricular confession. ${ }^{7}$ In opposition to the Cambridge Calvinists, Overall commended the use of private confession and defended its administration, a position shared by Lancelot Andrewes, the Bishop of Winchester, chaplain to Queen Elizabeth, and fatherconfessor at Pembroke College, Cambridge, and at St. Paul's. Indeed, Andrewes focused on priestly absolution in his sermon of the Power of Absolution, which elicited a widespread reaction at court after he delivered it at Whitehall in March $1600 . .^{8}$ In many ways, though, Andrewes' sermon reinforces the Church of England's established teachings on the doctrinal place of confession and absolution. He supports, for example, its position that only ordained clergy ('Ecclesiastical persons') have the ability to absolve sins, but that, in special circumstances, God can 'bestow it on whom or when Him pleaseth' (5: 92). Moreover, he follows the Established Church's rejection of the sacramental quality of confession.'

While Andrewes' evocation of 'the power of the keys' in this sermon corresponds to the doctrine of the Church of England, his emphasis on the necessity of private confession and the power of absolution opposes the Calvinistic elements in the church. Instead of relegating auricular penance to ex traordinary circumstance, as the Elizabethan Prayer Book instructs, he states that 'there are divers acts instituted by God and executed by us, which all tend to the remission of sins ... and in all and every of these is the person of the minister required, they cannot be dispatched without him' (5: 94-95). Andrewes' eschewing of the opinion that the selfexamination involved in private confession was an undue burden to an individual's conscience, as Luther and Calvin maintained, supports this anti-Calvinist interpretation, as does his accentuation on the limitations of an individual's faith due to scrupulousness and doubts: 'Sometimes men have good minds, but know not which way to turn them or set themselves about it ... For most usual it is for men at their ends to doubt, not of the power of remitting of sins, but of their disposition to receive it' (5: 101). In order to overcome these obstacles, Andrewes stresses the ability of auricular confession to effect immediately 'strong consolation and perfect assurance, [and] not waver in the hope which is set before them' (5: 102). Rather than elevate the individual's ability to overcome sin, then, he addresses the necessary intervention of a priest and intimates the sacramental quality of the rite of penance.

In his later sermons, Andrewes further emphasizes the centrality of auricular confession in Christian life. In Of the Sending of the Holy Ghost, which he delivered before King James at Whitehall in 1612, he describes the priest's 'second imposition of hands' in the rite of absolution as the 'third necessity' following baptism and 
confirmation in the lives of the faithful (3: 191). For Andrewes, an individual's interior disposition is inadequate to reconcile with God and requires auricular confession. Andrewes' views on the sacramental quality of the rite of penance, though they never drew extensive criticism or reprobation, mark a shift away from the Calvinist and Puritan inflected teachings of the sixteenth-century Established Church. Yet, as Maurice Reidy observes, his desire to return to 'the full devotional life of the old Church' intimates that his teachings on confession were indicative of a larger tension between the Calvinist and avant-garde strands that threatened to destabilize the media via of the Church of England (142). This division regarding the place of confessional practices would only intensify and become even more divisive in the Caroline church. ${ }^{10}$

\section{II}

In A Lover's Complaint, Shakespeare directly engages with the emerging controversy regarding auricular confession in the Church of England. He establishes the poem's confessional form in the opening narrative frame, and his description of the reverend man and his interaction with the fickle maid indicates the poem's confessional substructure in three ways. First, the epithet 'reverend' had been used to describe clergymen in England since the late fourteenth century." Second, Shakespeare's presentation of the reverend man as "[s]ometime a blusterer that the ruffle knew/ Of court, of city, and had let go by/ The swiftest hours, observed as they flew' suggests a minister who journeyed for a temporary ecclesiastical position and had returned to the country $(58-60) .{ }^{12}$ Third, the specific identification of the reverend man as a 'blusterer' (a braggart) also reinforces his occupation as a clergyman, for the verb 'to bluster' often had negative religious connotations in the sixteenth century. ${ }^{3}$ The reverend man therefore began his time in the court and the city as a braggart, but he 'observed' the 'swiftest hours' and learned from the experience. ${ }^{14}$ As 'Sometime' in line 58 illustrates, the reverend man was formerly a blusterer in the court and town; now he is 'privledg' $d$ by age' $(62) .{ }^{15}$ Following the tradition of the shepherd-priest depicted most famously in Spenserian poetics, which Patrick Cheney outlines in his essay in this collection, Shakespeare presents a reformed clergymen who has retired to the country to 'graz[e] his cattle' as well as to care for his spiritual flock (57). ${ }^{16}$

The reverend man's actions towards the fickle maid further evince his role as a priestly figure. This identification is not meant to suggest that the reverend man represents either a minister in the Church of England or a recusant Catholic priest. In contrast to Shakespeare's other religious figures, such as Friar Lawrence in Romeo and Juliet or Isabella in Measure for Measure, the reverend man's religious denomination is not identified. Nevertheless, his reaction to the maid's lamentations simultaneously advances his role as a confessor capable of exercising the power of absolution and distinguishes him from the Calvinist and Puritan positions regarding individual penitence. As such, upon finding the maiden 'shriking undistinguish'd woe, / In clamor high and low' (21-21) he approaches her 'fastly' (61) and 'desires to know / In brief the grounds and motives of her woe' (62-63). After this first entreaty, he proceeds to initiate the traditional form of private confession by 'comely 
distant sit[ting] by her side' (65). The etiquette of confession dictated 'that when a woman comes to confess, the priest should place her at his side so that he cannot look into her face'. ${ }^{17}$ Once the reverend man is seated, he again 'desires her ... / Her grievance with his hearing to divide' (67). The technical language of 'to divide' underscores his role as a confessor who will distinguish and classify her woes. ${ }^{18}$ Moreover, the conditional nature of his assistance highlights the fact that the reverend man possesses the ability to loosen or bind the fickle maid's sins: 'If that from him there may be aught applied / Which may her suffering ecstasy assuage, / 'Tis promis'd in the charity of age' (68-69). In other words, he cannot absolve her before determining the cause of her 'grievance' and her present spiritual condition. 'For it is not enough,' reminds Andrewes in Of the Power of Absolution, 'to be sorry for sin past, or to seek repentance, no though it be "with tears" ... if there be in our purpose to retain and hold fast our old sin still' $(5: 100)$. The reverend man must be certain about the fickle maid's contrition and sincere repentance to God before he can 'assuage' her 'suffering ecstasy.' The reverend man does not intentionally withhold spiritual comfort from the fickle maid; on the contrary, "in the charity of age' he wants to assist her, but he cannot determine whether he should absolve her or, if she remains unrepentant, exhort her to be contrite (70).

The fickle maid's responses to the reverend man's entreaties demonstrate her entrance into the confessional rite. For instance, she refers to him as 'Father' (71) and she explains that ' $[\mathrm{n}]$ ot age, but sorrow, over me yet hath power' attest (75)..$^{19}$ Her revelation of her 'too early' (78) relationship with 'a youthful suit' similarly follows a penitent's naming of grave sins (79). Instead of justifying her actions, she admits that unlike 'the general bosom ... / Of young, of old, of sexes both enchanted' (127-28), she remained 'in freedom' (144). And her admission that she 'was my own fee-simple' illustrates that she recognizes her culpability (144); she freely 'threw [her] affections in [the young man's] charmed power' and 'gave' him 'all [her] flower' (146-48). After briefly revealing 'the grounds and motives of her woe,' expressing through her sorrow and self-accusations her contrition, and indicating her desire for God's forgiveness, the fickle maid's confession seems to have reached its culmination. In short, she has fulfilled the reverend man's initial requests. Instead of ending, though, the fickle maid's confession doubles back on itself and is complicated by her doubts and self-justifications. Shakespeare underscores this regressive movement syntagmatically in lines 148-49: 'Yet did I not as some my equals did/ Demand of him, nor myself being desired yielded' (148-49, emphasis added). Now the fickle maid returns to the difference between herself and 'proofs new bleeding which remained the foil/ Of this false jewel' (153-54), a graphic description of the other virgins deflowered by the young man, not to emphasize her responsibility, but to evince how she her 'honor shielded' (151). This contradictory movement between contrition and self-justification causes her confession to waver and apparently collapse when she transfers the motive of her transgression from her free will to the young man's 'subduing tongue' (120): 'And long these terms I held my city, Till thus he began to besiege me' (176-77).

While the fickle maid condemns the young man's 'foul adulterous heart,' her rewording of his seductive rhetoric emphasizes her shift from repentance to exculpation (175) ${ }^{20}$ By repeating the young man's 'art of craft,' she offers a justification for her capitulation to his seductive rhetoric (295). Rather than acting 
freely, she outlines her participation in a duplicitous religious economy in which grace stems not from God, but from the young man. In this false system of devotion, the young man resignifies grace and recenters it on himself. In short, he substitutes himself for God as an object of religious devotion: 'Religious love put out religion's eye' (250). He thus receives 'tributes' and redistributes them, for, as he explains, 'Nature hath charged me that I hoard them not, / But yield them up where I myself must render' (220-21). Because the young man elevates the fickle maid to the role as the 'origin and ender' (222) in this theological system, her refusal of the young man - her 'minister' (229) - would deleteriously affect the other women - 'broken bosoms' - who rely upon him (254). ${ }^{21}$ She would not only reject his 'holy vows,' but also those of the women who '[h] ave emptied all their fountains in [the young man's] well' (255). They, too, will feel his heartache: 'Feeling it break, with pleading groans they pine, / And supplicant to your sighs extend / To leave that batt'ry that you make 'gainst mine' (275-77). The fickle maid's decision to 'sh[ake] off my sober guards and civil fears' did not result from selfishness, but rather out of sympathy (298). Therefore, even though she condemns the young man's dissimulation - that 'hell of witchcraft lies / In the small orb of one particular tear' (288-89) - she explains her inability to resist his request: 'But what with the inundation of the eyes / What rocky heart to water will not wear?' (290-91). Since 'not a heart which in his level came / Could 'scape the fail of his all hurting aim,' she intimates that she cannot be entirely to blame for her transgression (309-10).

The fickle maid cannot, however, completely excuse her actions, for she admits the hollowness and theatricality of the young man's seductive rhetoric. Once she finishes rewording his speech, she clearly recognizes that she is no longer 'mighty' (253) and 'o'er [him] strong being' (257). She details his insincerity and laments her fallen state: 'When he most burnt in heart-wish'd luxury/ He preach'd pure maid, and prais'd cold chastity' (314-15). Moreover, she associates herself with Evestating, 'I fell' (321) - and then compares the young man to Satan: 'merely with the garment of a Grace/ The naked and concealed fiend ... cover'd' (316-17). ${ }^{22}$ Yet any resolution or contrition remains impossible because of the fickle maid's appropriation and internalization of the young man's seductive rhetoric. Her continued use of the young man's reoriented concept of grace illustrates that despite her proclamation of ' $O$ father, what a hell of witchcraft of lies/ In the small orb of one particular tear!' she remains situated within his false religious economy (288-89). ${ }^{23}$

Just as the 'sacred nun' forsook her 'die[t] in grace' (260) for the young man, so too does the fickle maid place herself into this system in which 'all these hearts ... on [his] depend' (274). For both women, as Patrick Cheney observes, '[s]exual desire evaporates Christian faith, instantly. This is a haunting idea, and must have been specially so to readers during the Reformation' (Shakespeare, National PoetPlaywright). Indeed, when the fickle maid begins to retell her sorrows to the reverend man, she identifies her seducer as the source and depository of grace - not Christ. She explains that others '[p]iec'd not his grace but were all grac'd by him' instead of attributing any $\sin$ to him (118-19). This description reiterates the young man's explanation that his former loves did not affect him: 'Harm have I done to them, but never was harmed/ Kept hearts in liveries, but in mine own was free/ And reign'd commanding in his monarchy' (194-96). The fickle maid accepts that his 'offenses .../ Are errors of the blood, none of the mind' (184-85) and also applies 
this reasoning to her own transgression: 'His poisn'd me, and mine did him restore' (301). In so doing, she unknowingly furthers the young man's deceptive theological system even as she uncovers the 'fiend' beneath 'the garment of a Grace." ${ }^{24}$

At the conclusion of A Lover's Complaint, moreover, the fickle maid remains infected by the young man's seductive theological rhetoric. Her final instance of self-justification - 'Who, young and simple, would not be so lover'd?' - is undercut by her subsequent lament: 'Ay, me, I fell, and yet do question make/ What I should do again for such a sake' (320-22, emphasis added). Neither capable of unequivocally confessing her transgression nor rejecting the shame of her fall, she continues to languish in the young man's deceptive rhetoric (see Heather Dubrow's essay in this volume). After cataloguing the young man's tempting attributes, however, Shakespeare reveals that despite the fickle maid's seemingly failed confession and continual attempts to rationalize her actions, she has been 'reconciled': 'Would yet again betray the fore-betray'd/ And new pervert a reconciled maid' (327-28, emphasis added). The meaning of 'reconciled' in this context could range from a formal reentry into the church to a feeling of consolation. ${ }^{25}$ Yet Shakespeare's decision to conclude the poem before closing the narrative frame extinguishes the possibility that the fickle maid achieves consolation. This ending, as John Kerrigan notes, 'raises as many problems as it solves. ... Are we to think that the maid's finding an audience has helped purge her lapse, or should we conclude that in line 329 she is merely salving herself?' (The Sonnets 425 , emphasis in original). If the young maid's reconciliation is not a 'self projection,' but a genuine reconciliation to God, then Shakespeare offers A Lover's Complaint as an interrupted, maimed rite (Kerrigan, The Sonnets 425). The fickle maid's confession accomplishes its spiritual purpose -it allows her to articulate her sorrows and experience contrition - but it leaves her in a state of uncertainty because her withdrawal into 'rapt subjectivity' precludes the reverend man's completion of the confessional rite (Kerrigan, Motives of Woe 51).

\section{III}

By collapsing the rite of penance, Shakespeare advances that the fickle maid's interiority cannot provide any distance from which to separate herself from the taint of sin. At the start of the poem, her 'plaintive story' (2) is 'reworded from a sist'ring vale' (1), and the narrator describes her tears as 'Laund'ring the silken figures in the brine / That seasoned woe had pelleted in tears' (17-18). The fickle maid first appears as locked within melancholic repetition-a state representative of her interior subjectivity. Consequently, as Shirley Sharon-Zisser explains, '[T]he melancholic lover's 'fluxive eyes' are indeed synecdochic of the dissolution of the subject, a state in which 'mind and sight' become 'distractedly commix'd' (202). Further, the fickle maid's subsequent recourse to interiority merely causes her to vacillate between self-doubt and guilt, and, in the process, to reinscribe herself within the young man's seductive rhetoric. When compared with the Sonnets the fickle maid's position at the conclusion of the poem recalls that of Will, who explains in Sonnet 62: 'And for this sin there is no remedy,/ It is so grounded inward in my heart' (3-4). Moreover, both figures repeatedly express a willingness to lie to 
themselves and to accept their self-deceptions as truth. ${ }^{26}$ As Katherine Duncan-Jones observes: 'The Sonnets-speaker finds himself ultimately trapped in a web of his own poetic fabrication ... The maid, analogously, in attempting both to justify her sexual fault and to purge herself of the weakness that led to it, discovers that in rewording the youth's wooing speeches she is captivated by them all over again' (Shakespeare's Sonnets 94). In Sonnet 138, for instance, Will explains in the couplet: 'Therefore I lie with her, and she with me, / And in our faults by lies we flattered be' (13-14). ${ }^{27}$ Likewise, the fickle maid remains attracted to the young man's 'false fire' (324) and 'borrowed motion' (327) even though she knows he is a 'fiend' and a 'tempter' (317-18). Will and the fickle maid are thus connected by similarly deceptive objects of desire as well as by their repeated attempts to process the shame and guilt stemming from their sexual transgressions.

However, whereas in the Sonnets Will transforms the various anxieties and sufferings stemming from his relationship with the young man and dark lady into an opportunity for poetic introspection, the fickle maid is paralyzed by her sexual transgression. To use Lars Engel's terminology, she fails to establish a 'resistant interiority' that uses shame 'to clear evaluative space' (195-96). Unlike the interior monologues of the sonnet speaker, moreover, she requires external intervention to move beyond the 'concave womb [that] reworded/ A plaintive story' and to negotiate Christian sin and guilt (1-2). Finally, her retreat into interior subjectivity at the conclusion of the poem causes her to come full circle and leaves her in a paralyzed, circular desire. Therefore, if Joel Fineman is correct in contending that Shakespeare presents in the Sonnets a 'fracture of identity ... [that] justifies and warrants poetic introspection,' in A Lover's Complaint this 'insufficiency' leads only to anxious, unproductive self-examination (77). The fickle maid's 'undistinguish'd woe' evaporates any productive, explorative poetic space created in the Sonnets. ${ }^{28}$ Similarly, her destruction of the young man's 'folded schedules' (43) and 'deep brain'd sonnets' (208) exposes the fundamental instability underlying Will's confidence in Sonnet 55 about his 'pow'rful rhyme' (2). By effacing Will's interior development in A Lover's Complaint, Shakespeare indicates the inherent limitations of the mode of individual subjectivity and poetic expression established in the Sonnets.

In A Lover's Complaint Shakespeare thus intensifies the connection between the destructive 'errors of the blood' (184) and the 'mind' (184) introduced in Sonnet 147: 'Desire is death' (8). ${ }^{29}$ In so doing, he indicates little confidence in the ability of individuals to extricate themselves from this fatal system of desire and deception. Yet the intrusion of the reverend man into the fickle maid's plaintive landscape and his reorientation of her sorrows into confessional space intimate the possibility of reprieve from 'heaven's fell rage' through ritual. This movement responds not only to the plight of the fickle maid, but also to Will's sickness and madness, which results from his broken bed-vows and perjured oaths. And although the fickle maid's and reverend man's failure to complete the rite of penitence causes her to regress into self-doubt, her ability to articulate the 'motives of her woe' after the reverend man's entreaties nevertheless suggests the productiveness of ritual in Shakespeare's conception of individual subjectivity. Moving beyond the Protestant assurance of faith and self-discipline, he signals that an individual cannot overcome sin or experience consolation without external intervention-such as the outside voices of 
the reverend man and female speaker in Sonnet 145 that 'sav'd my life' (14). In the end, Shakespeare reveals that ritual offers a way out from the world of the young man, that it can restore a 'more perjur'd eye,' that it can even make whole a 'reconciled maid' (Sonnets 152.13). Shakespeare's positive representation of the rite of confession therefore indicates his support of ceremonialism, the position advocated by Andrewes and other early Jacobean avant-garde preachers, and his distance from the Calvinist majority in the Church of England. ${ }^{30}$

\section{Notes}

1 All quotations from A Lover's Complaint and the Sonnets are taken from John Kerrigan's The Sonnets and A Lover's Complaint. Quotations from Shakespeare's other works are taken from The Riverside Shakespeare 2nd Ed., ed. G. Blakemore Evans (New York: Houghton Mifflin, 1997).

2 For critics who suggest that the fickle maid exaggerates her complaint, see Underwood 38; Kerrigan, Motives of Woe 51; and Mehl 138. Critics who posit that the fickle maid resolves her conflict include Underwood 101; Laws 85; Craik 457; and Roberts 150.

3 Kerrigan describes confessional practices in Reformation England as being constant throughout the period; see Motives of Woe 40.

4 In this essay, I accept Shakespeare's authorship of A Lover's Complaint as well as Katherine Duncan-Jones' argument in 'Was the 1609 Shakes-speares Sonnets Really Unauthorized?' for his authorization of the 1609 quarto. The question of Shakespearean authorship has recently been reopened; see Elliott 196-201; and Vickers.

5 On the significance of the Lateran reform of confession, see Payer 126.

6 For an overview of The Order of Communion, see Cuming 61-62.

7 On the particulars of the controversy surrounding Overall, see Tyacke, Anti-Calvinists $110-11$.

8 See Rowland White's letter to Robert Sidney, rpt. in Andrewes 11: 1xii.

9 On Andrewes' support of the general position of the Church of England, see Gibbs.

10 See Tyacke, Anti-Calvinists 221-22.

11 The $O E D$ (def. 2.a) defines reverend as 'a respectful epithet applied to members of the clergy' and cites Shakespeare's Henry VIII IV.ii.1 - 'The reuerend Abbot With all his Couent honourably received him' - as a representative usage of the word in the early seventeenth century.

12 The economic difficulties facing the lower clergy in the late Elizabethan period were substantial and often caused ministers to seek various types of employment, such as university fellowship, assistant curate, or reader. See O'Day 50-102.

13 All of the examples given in the $O E D$ (def. 4) of the verb bluster - 'To utter with a blast, or with stormy violence or noise' in the sixteenth century have a religious connotation. The citation from Thomas Cranmer's Catechism illustrates this clearly: 'These more then deullish swerers ... do blowe \& bluster oute of theyr ungodly mouthes such blasphemies.' The OED cites A Lover's Complaint as the first example of blusterer, which is defined as 'One who utters loud empty boasts or menaces; a loud or inflated talker, a braggart'. This definition does not undercut the reverend man's religious occupation; rather, it indicates his previous shortcomings as a minister.

14 As Colin Burrow notes in his gloss to lines 59-60: the reverend man is one "who had allowed the rapidly passing days of youth to slip away, but who had drawn instruction from them (observed)' (699).

15 The primary meaning of age is, of course, elderly; see $O E D$ def. 6. But it also corresponds to $O E D$ def. 3: 'Such duration of life as ordinarily brings body and mind to 
full development, years of maturity or discretion, or what by law and custom are fixed as such.'

16 The reverend man's occupation as a cattle herder does not preclude him from religious occupation. In fact, rural clergy regularly supplemented their income through raising livestock.

17 Tentler 82; see also Nichols 150-51.

18 Rollins glosses: 'deuide] Schmidt (1874): Share, communicate.' Most editors follow this reading (340). For instance, Kerrigan writes: 'Her grieving with his hearing to divide. The reverend man invokes proverbial lore, "Grief is lessened when imparted to others" (compare The Passionate Pilgrim VV.53-8), "When shared, joy is doubled and sorrow halved," while the poet plays on grievance (both cause, and, by extension, effect of "grief") and emphasizes, once more, verbal "doubleness" (divide as "share evenhandedly")' (The Sonnets 404). However, as Marvin Spevack shows, of the twenty-six uses of 'divide' in Shakespeare's works, the majority denote separation rather than sharing (326).

19 Kerrigan writes: 'Not a melodramatic revelation of identity but-as at line 288 and, for instance, Coriolanus V.1.3-a title of respect used of old and venerable men. Arguably, the maid's predicament, the reverend man's care, and the confessional nature of what is to follow make the 'ghostly father, confessor' contribute to the vocative's ring' (The Sonnets 404). Given what precedes the fickle maid's confession, I would further posit that 'Father' simply confirms the reverend man's identity.

20 See Ilona Bell's essay in this collection for a discussion of $A$ Lover's Complaint as a nonreligious, exculpatory complaint.

21 On the young man's strategy of seduction, see Roe 69.

22 For an examination of the fickle maid's relationship to Eve, see Muir 164.

23 Stressing the emotional situation of the fickle maid, Katherine Duncan-Jones notes: '[T]he 'fickle maid' is already touched by 'seared age' (14), and finds that she is unable to free herself from emotional dependence on the betraying words of her lover ... And though poetic language may beautify, promote or redefine desire, in the process of so doing it, too, becomes infected' (Shakespeare's Sonnets 95).

24 Ilona Bell remarks that the male lover 'brags shamelessly about his ability to project his "shame" onto his lovers' (467).

25 Rollins notes: 'reconciled] LEE (ed. 1907) A repentant maid, one who has expiated her sin.-POOLER (ed. 1918): Readmitted to the Church after excommunication' (366). Similarly, Burrow glosses reconciled as 'reformed, repentant. $O E D$ sense 5 a of "reconcile" may be germane, given that the "father" to whom the confession is made has priestly overtones (he is a reverend man at 1.57): "To bring back, restore, or readmit to the Church, spec, the Church of Rome"' (717).

26 Referring to Sonnet 35, Heather Dubrow observes: 'But the most disturbing of the deceptions in the sequence are the speaker's self-deceptions. By shaping so many of the poems as internalized lyrics, Shakespeare provides a forum for his speaker's repeated attempts to lie to himself' (65).

27 The speaker of the sonnets expresses a similar awareness of his self-deception in Sonnet 152: 'For I have sworn thee fair: more perjured eye/ To swear against the truth so foul a lie' (13-14).

28 The mediation of the unnamed narrator further indicates the absence of poetic creation in A Lover's Complaint; see Kerrigan, Motives of Woe 40-45.

29 On the significance of this passage for Shakespearean desire, see Dollimore 381-82.

30 For a more complete discussion of Shakespeare's advocacy of the ceremonialist position in his poems and plays, see my forthcoming dissertation Rites of Authorship: Early Modern Ritual in Spenser, Shakespeare, and Donne. 